\title{
Şap virusu ile enfekte ve aşılı danalarda serum proteinlerinin elektroforetik dağılımı*
}

\author{
Zeynep Sanem OR, Ulvi Reha FIDANCI
}

Ankara Üniversitesi Veteriner Fakültesi Biyokimya Anabilim Dalı, Ankara.

\begin{abstract}
Özet: Şap hastalığı bütün geviş getiren çift tırnaklı hayvanlar ile domuzlarda görülen akut, ateşli ve bulaşıcı viral bir enfeksiyondur. Şap hastalığına ilişkin araştırmalar genel olarak hücre kültürleri ile gerçekleştirilen çalışmalardır. Şap hastalığına yakalanan hasta hayvanlar üzerinde gerçekleştirilen çalışmalar ise son derece azdır. Bu çalışmada, sağliklı, şap hastalıklı ve şap hastalığına karşı aşılanmış erkek danalarda serum protein elektroforezi ile albumin, alfa-1-globulin, alfa-2-globulin, beta-globulin ve gama-globulin düzeyleri belirlenmiş ve hastalığın protein metabolizması ile ilişkisinin araştırılması amaçlanmıştır. Danaların hepsi şap virüsü ile enfekte edilmeden ve aşılanmadan önce sağlıklı grubu oluşturmuşlardır. Daha sonra danalardan 10 baş O1 tipi şap virüsü ile enfekte edilerek hastalıklı grubu, 10 baş ise $\mathrm{O} 1$ tipi şap virüsüne karşı aşılanarak aşılı grup oluşturulmuştur. Danalardan alınan kan serumu örneklerinde toplam protein tayini biüret yöntemi ve serum protein elektroforezi ise agaroz-jel elektroforez yöntemi ile gerçekleştirilmiştir. Hastalık oluşturulmadan veya aşılanmadan önceki sağlıklı dönemde alınan sonuçlarla karşılaştırıldığında, sadece aşılama sonrası dönemde albumin seviyesinde önemli bir azalma ve gama-globulin seviyesinde önemli bir yükselme olduğu görülmektedir $(\mathrm{p} \leq .0 .001)$. Bu değişikliklerin inaktif viruslarla aşılamada, organizma tarafından daha kısa sürede oluşturulan immun yanıta bağlı olabileceği kanaatine varılmıştır. Şap hastalığı ve şap hastalığına karşı aşılanmış hayvanlarda genel olarak klinik biyokimyasal verilerin yetersiz olması-bulunması, gelecekte benzer araştırmaların sürdürülmesinin son derece önemli olduğunu göstermektedir.
\end{abstract}

Anahtar sözcükler: Dana, serum protein elektroforezi, şap aş1sı, şap hastalığı

\section{Serum protein electrophoretic distribution of calves infected with and vaccinated against foot and mouth disease (FMD)}

Summary: Foot and mouth disease (FMD) is an acute, feverish and contagious viral infection that can be seen in all ruminating double nailed animals and pigs. Studies on this disease are generally based on cell cultures. The numbers of researches on animals that have actually contracted the disease are very few. The aim of the study was to investigate the relationship between the disease and protein metabolism. Serum electrophoresis and alpha-1-globulin, alpha-2-globulin, beta-globulin and gamma-globulin levels of healtly cows, cows with FMD and vaccinated cows were determined. Healthy group consists of the cows that haven't infected with disease or vaccinated. Then, 10 of the cows were infected with $\mathrm{O}_{1}$ type virus and formed the sick group and 10 was vaccinated against $\mathrm{O}_{1}$ type virus and formed the vaccinated group. The total protein determination of the blood plasma samples taken from the cows was made by using biuret method and the plasma protein electrophoresis of the same samples was made by using agarose-gel electrophoresis. When compared with the healthy period, which is before infection or vaccination, a significant drop in albumin and rise in gamma-globulin levels $(\mathrm{p} \leq .0 .001)$ was observed after the vaccination. These changes could be related to the immune reaction created by the organism in a shorter time as a counteract against vaccination with inactive viruses. Insufficient clinic biochemical data on FMD and vaccinated animals clearly demonstrates the need for similar studies in the future.

Key words: Calf, foot and mouth disease (FMD), FMD vaccine, serum protein electrophoresis.

\section{Giriş}

Şap hastalığı sığır, koyun, keçi gibi bütün geviş getiren çift tırnaklı hayvanlar ile domuzlarda görülen akut, ateşli ve bulaşıcı bir viral enfeksiyondur (17). Şap hastalığının etkeni Picornaviridae familyasının aphtovirus alt grubunda yer alan zarsız, tek iplikçikli RNA içeren bir virustur ve $\mathrm{O}, \mathrm{A}, \mathrm{C}$, SAT 1 , SAT 2, SAT 3 ve Asia 1 olmak üzere 7 farklı serotipi vardır. O serotipinin 11, A serotipinin 32, C serotipinin 5, SAT 1 serotipinin 1, SAT 2 serotipinin 3, SAT 3 serotipinin 4 ve Asia 1 serotipinin de 1 alt tipi bulunmaktadır $(6,10,16,18)$.

Hayvanlarda şap hastalığınının metabolik etkilerini incelemek amacıyla hücre kültürlerinde çok sayıda araştırma gerçekleştirilmiş olmasına karşın, canlı hayvanlar

\footnotetext{
* Bu çalışma Bio. Zeynep Sanem Or’un "Şap virusu ile enfekte ve aşılı danalarda serum protein elektroforezi” başlıklı Yüksek Lisans Tezinden özetlenmiştir. Tez çalışması etik kurallara uygun olarak yapıllmıştır.
} 
üzerinde gerçekleştirilen araştırmalar son derece azdır $(4,11,17,19)$.

Şap virusu, sığır tiroid hücre kültüründe, domuz ve koyun böbrek hücre kültürleri, dil epitel hücrelerini içeren hücre kültürlerinde üretilebilir (7). Hücre kültüründe yapılan bir çalışmada glikolitik aktivitedeki artışın virus üremesi ile ilişkili olduğu belirlenmiştir. Şap virusu ile enfekte hücre kültürlerinde pürivik asit oluşumunun normal kültürlere oranla daha az olduğu gözlenmiştir. Tavşanlarda yapılan çalışmada ise virus inokulasyonundan sonra kalp kasında laktik asit oluşumunda artış saptanmıştır (13).

Şap Enstitüsü tarafından yapılan saha çalışmalarında hastalıktan ani olarak ölen birçok genç hayvanın otopsileri yapılmış ve bu hayvanların miyokart enfarktüsünden öldükleri saptanmıştır (18).

Şahal ve ark. (1994) yaptı̆̆ bir çalışmada (19) şap hastalığı geçirmiş ineklerin enfeksiyondan sonraki 60 ve 70 inci günlerinde yapılan klinik muayenelerinde saptanan kondüsyon kaybı, kaslarda zayıflık, polidipsi, poliüri ve rumen hareketlerinde azalma belirtileri, şap hastalığ ve Bovine virus diyare, enfeksiyonu geçirmiş ineklerde bu hastalıkları komplikasyonu olarak şekillenen Diabetes Mellitus gözlemlendiği bildirilmiştir.

Bölükbaşı ve ark. (1987) da (2), Türkiye'de sığırlarda verim düşüklügü ve ölüm nedeniyle büyük ekonomik kayıplara yol açan O1 serotipi şap virusunun oluşturduğu çeşitli bozuklukların kalbin biyoelektriksel potansiyelinin etkilendiği, düzenini kaybettiği ve elektrokardiyagramlarda önemli değişikliklere neden olduğu saptanmıştır.

Başka bir çalışmada (11) şap virusu ile enfekte dişi sığırlarda $\beta$-karotin ve vitamin A değerlerinin düştüğü ve bunun şap hastalığına bağlı günlük vitamin A ihtiyacının artmasından ve fazla vitamin A kullanımından kaynaklanabileceği bildirilmiştir. Şap hastası dişi buzağ 1 ve danaların serum vitamin E düzeylerinin sağlıklı olanlara oranla yüksek olduğu gözlenmiştir.

Coşkuner (2003) yaptığı bir çalışmada (4), şap hastalığının akut döneminde toplam kolesterol, toplam lipid, trigliserid ve VLDL-kolesterol değerlerinin düşmesi suretiyle şap hastalığı ve buna karşı aşılamanın lipid metabolizmasını etkilediği saptanmıştır.

Bu çalışmada, sağlıklı, şap hastalıklı ve şap hastalığına karşı aşılanmış danalarda serum protein elektroforezi ile albumin, alfa-1-globulin, alfa-2-globulin, betaglobulin ve gama-globulin düzeyleri belirlenmiş ve şap hastalığında serum protein fraksiyonlarındaki dağılımın incelenmesi amaçlanmıştır.

\section{Materyal ve Metot}

Çalışmada, hayvan materyali olarak Tarım ve Köyişleri Bakanlığı (TKB) Şap Enstitüsü’nde aynı bakım ve besleme şartlarında kontrollü izole ahırlarda barındırılan 12-18 aylık 20 adet erkek dana kullanılmıştır.
Çalışmada kullanılan danaların hepsi şap hastalığına karşı antikorsuz olup, Şap Enstitüsü bünyesinde kapalı ahır sisteminde kaliteli kuru ot, saman ve kesif besi yeminden oluşan rasyonla beslenmişlerdir.

Çalışmada kullanılan hayvanlar, sağlıklı, şap hastalıklı ve şap hastalığına karşı aşılanmış danalar şeklinde gruplandırılmıştır. Danaların hepsi şap virüsü ile enfekte edilmeden ve aşılanmadan önce sağlıklı grubu oluşturmuşlardır. Daha sonra danaların 10 başı O1 tipi şap virüsü ile enfekte edilerek hastalıklı grubu, 10 baş ise O1 tipi şap virüsüne karşı aşılanarak şap hastalığına karşı aş11 grubu oluşturmuştur.

Hastalıklı grubu oluşturan danaları deneysel olarak enfekte etmek için O1 (104 ID50 enfektif dozda) tipi şap virüsü, aşılı grubu oluşturan danaların aşılanmasında TKB Şap Enstitüsü Üretim Laboratuvarları'nda O1 Manisa tipi şap virüsüne karşı üretilmiş ve kontrolleri yapılmış monovalan şap aşısı kullanılmıştır.

Aşılar, TKB Şap Enstitüsü protokolüne uygun olarak danaların gerdan bölgesine $5 \mathrm{ml}$ deri içi olarak uygulanmıştır. Enfekte gruptaki danalarda virus, yine TKB Şap Enstitüsü protokolü uyarınca, danaların dilinin iki noktasından $0.1 \mathrm{~mL}$ intradermolingual olarak inokule edilmiştir (20).

Kan örnekleri aş1l gruptan aşılama öncesi ve aşılama sonrası 21. günde, hastalıklı gruptan ise hastalık öncesi ve klinik belirtiler gözlendikten sonra, bir günlük açlık periyodu sonrasında, antikoagülan madde içermeyen vakumlu kan alma tüpleri kullanılarak alınmıştır. Kan örnekleri 1 saat oda sıcaklığında bekletildikten sonra 3000 rpm'de 10 dakika santrifüj edilerek serumları ayrılmış ve analizler gerçekleştirilinceye kadar $-80{ }^{\circ} \mathrm{C}$ de muhafaza edilmiştir.

Serum örneklerinde toplam protein tayini biüret yöntemi ile (20) ve protein elektroforezi ise agaroz-jel elektroforez yöntemi ile ticari kit kullanılarak gerçekleştirilmiştir $(12,21)$. Protein elektroforezi sonrasında bantlar dansitometrede $600 \mathrm{~nm}$ 'de okunarak protein \% fraksiyonları elde edilmiştir.

Sağlıklı hayvanlar ile şap hastalıklı ve şap hastalığına karşı aşılanmış danalardan elde edilen değerler istatistik olarak eşyapma yöntemi ile karşılaştırılmıştır (5).

\section{Bulgular}

Şap virusu ile enfekte edilmeden önce, sağlıklı danalardan ve enfekte edilerek hastalık oluşturulduktan sonra danalardan alınan serum örneklerinde gerçekleştirilen toplam protein değerleri $(\mathrm{g} / \mathrm{dl})$ ve serum protein elektroforezi ile belirlenen \% albumin, alfa-1-globulin, alfa-2-globulin, beta-globulin, gama-globulin sonuçları ve istatistik değerlendirmeleri Tablo 1'de, her iki grubun serum proteinlerine ait elektroforez bantları ve bu protein bantlarının dansitometrik değerlendirmesine ait birer örnek Şekil 1- 4 de gösterilmiştir. 
Tablo 1: Sağlıklı ve şap hastalıklı danalarda serum proteinlerinin elektroforetik dağglımı Table 1: Electrophoretic distribution of serum proteins of healthy calves and the ones with FMD

\begin{tabular}{lcccccc}
\hline Serum Proteinleri & $\mathrm{N}$ & Sağlıl1 & Hastalıkl & $\mathrm{T}$ & Df & Sig. \\
\hline Toplam protein (g/dL) & 10 & $8.54 \pm 0.25$ & $8.36 \pm 0.32$ & 0.375 & 9 & 0.716 \\
Albumin (\%) & 10 & $38.30 \pm 0.72$ & $36.70 \pm 1.07$ & 1.003 & 9 & 0.342 \\
Alfa-1-globulin (\%) & 10 & $7.29 \pm 0.17$ & $6.76 \pm 0.22$ & 1.767 & 9 & 0.111 \\
Alfa-2-globulin (\%) & 10 & $10.82 \pm 0.26$ & $11.53 \pm 0.40$ & -1.686 & 9 & 0.126 \\
Beta-globulin (\%) & 10 & $11.74 \pm 0.29$ & $12.68 \pm 0.30$ & -1.810 & 9 & 0.104 \\
Gama-globulin (\%) & 10 & $31.85 \pm 0.59$ & $32.33 \pm 0.79$ & -0.418 & 9 & 0.685 \\
\hline
\end{tabular}

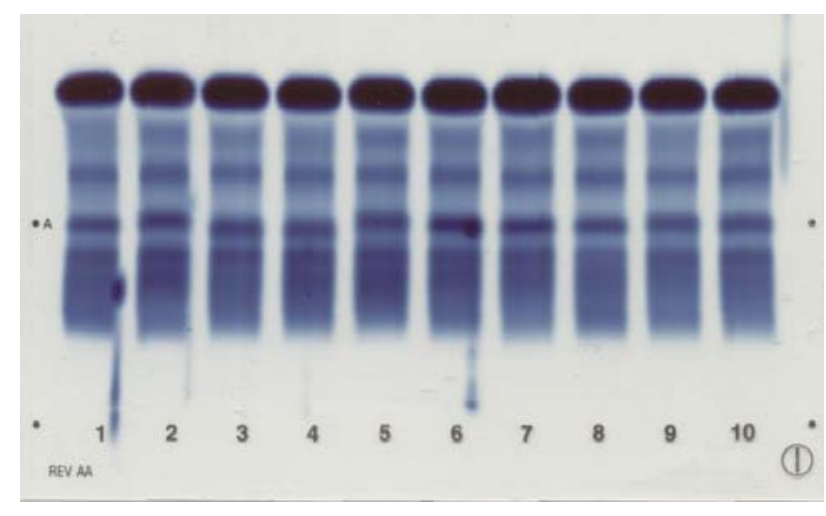

Şekil 1: Sağlıklı danalarda (hastalık oluşturulmadan önce) serum proteinlerine ait elektroforez bantları

Figure 1: Serum protein electrophoresis bands in healthy calves (before infection)

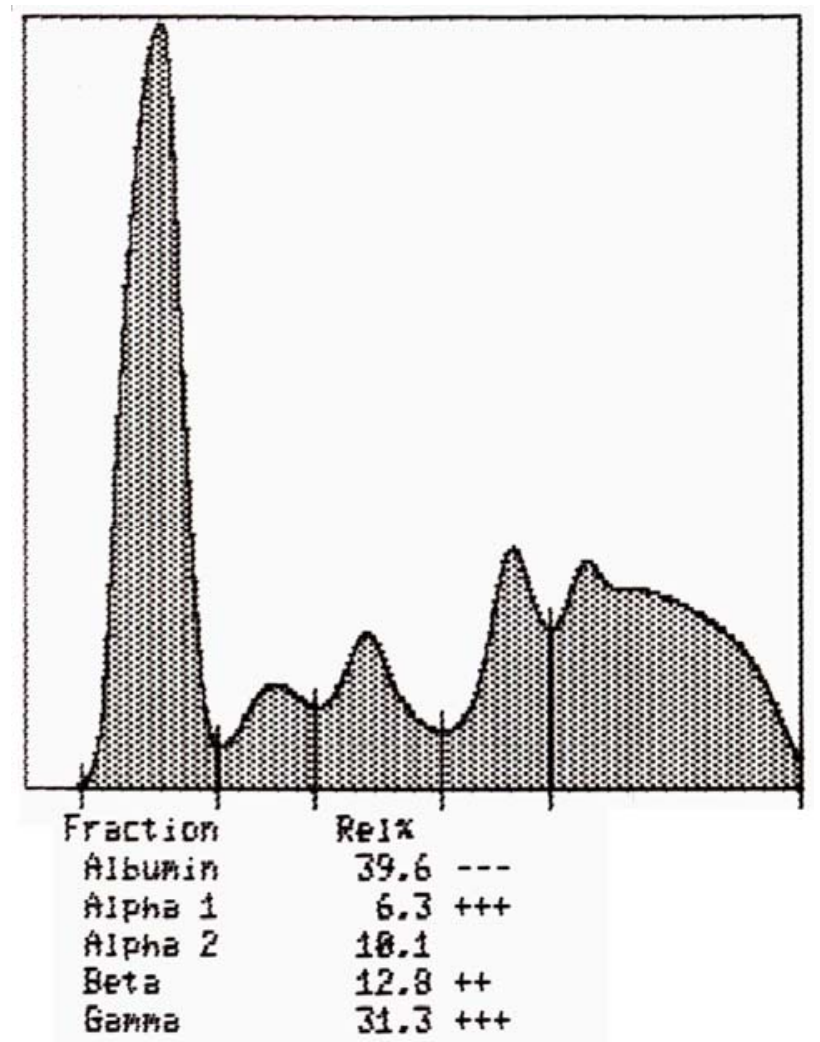

Şekil 2: Sağlıklı danalarda serum protein bantlarının dansitometrik değerlendirilmesi

Figure 2: Dansitometric evaluation of protein bands in healthy calves (before infection)

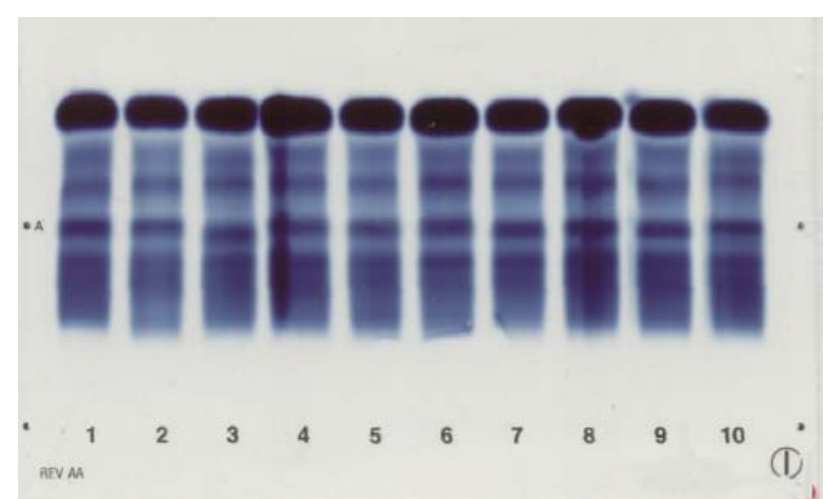

Şekil 3: Şap hastalıklı danalarda serum proteinlerine ait elektroforez bantları

Figure 3: Serum protein electrophoresis bands of calves infected with FMD virus

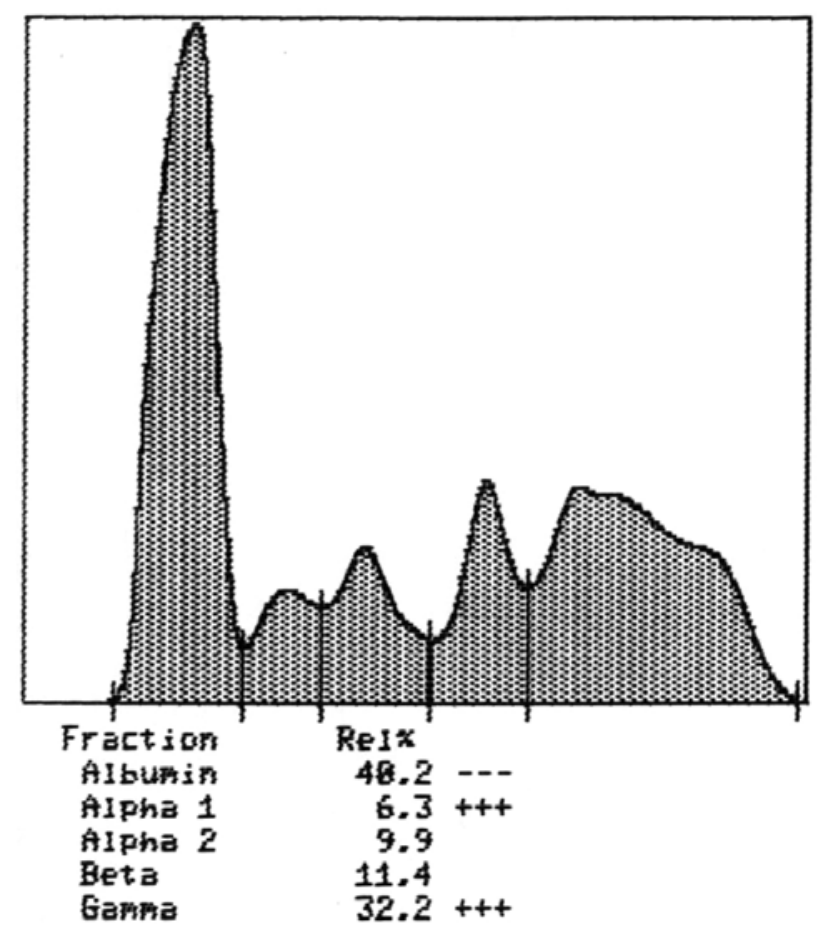

Şekil 4: Şap hastalıklı danalarda serum protein bantlarının dansitometrik değerlendirilmesi

Figure 4: Dansitometric evaluation of protein bands in calves infected with FMD virus 
Şap hastalığına karşı aşılanmadan önce, sağlıklı danalardan ve hastalığa karşı aşılandıktan sonra danalardan alınan serum örneklerinde gerçekleştirilen toplam protein $(\mathrm{g} / \mathrm{dL})$ ve serum protein elektroforezi ile belirlenen yüzde albumin, alfa-1-globulin, alfa-2globulin, beta-globulin, gama-globulin sonuçları ve istatistik değerlendirmeleri Tablo 2'de, her iki grubun serum proteinlerine ait elektroforez bantları ve bu protein bantlarının dansitometrik değerlendirmesine ait birer örnek Şekil 5- 8 de gösterilmiştir.

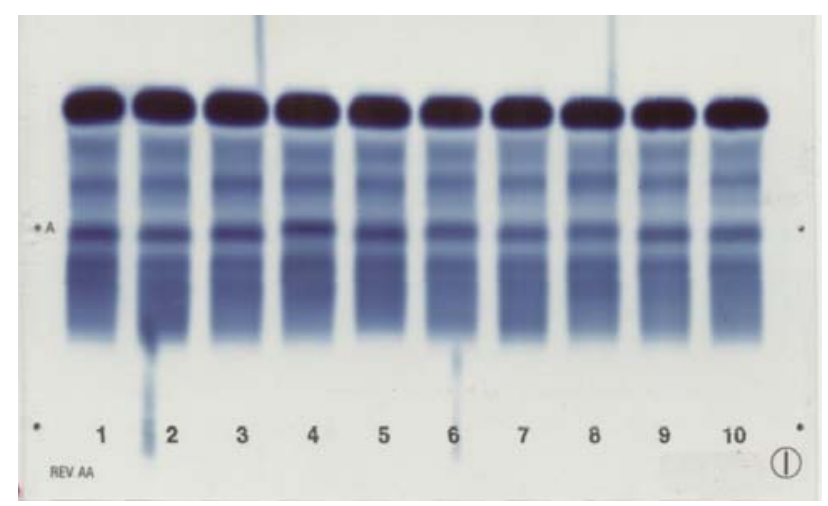

Şekil 5: Sağlıklı danalarda (aşılamadan önce) serum proteinlerine ait elektroforez bantları

Figure 5: Serum protein electrophoresis bands in healthy calves (before vaccination)

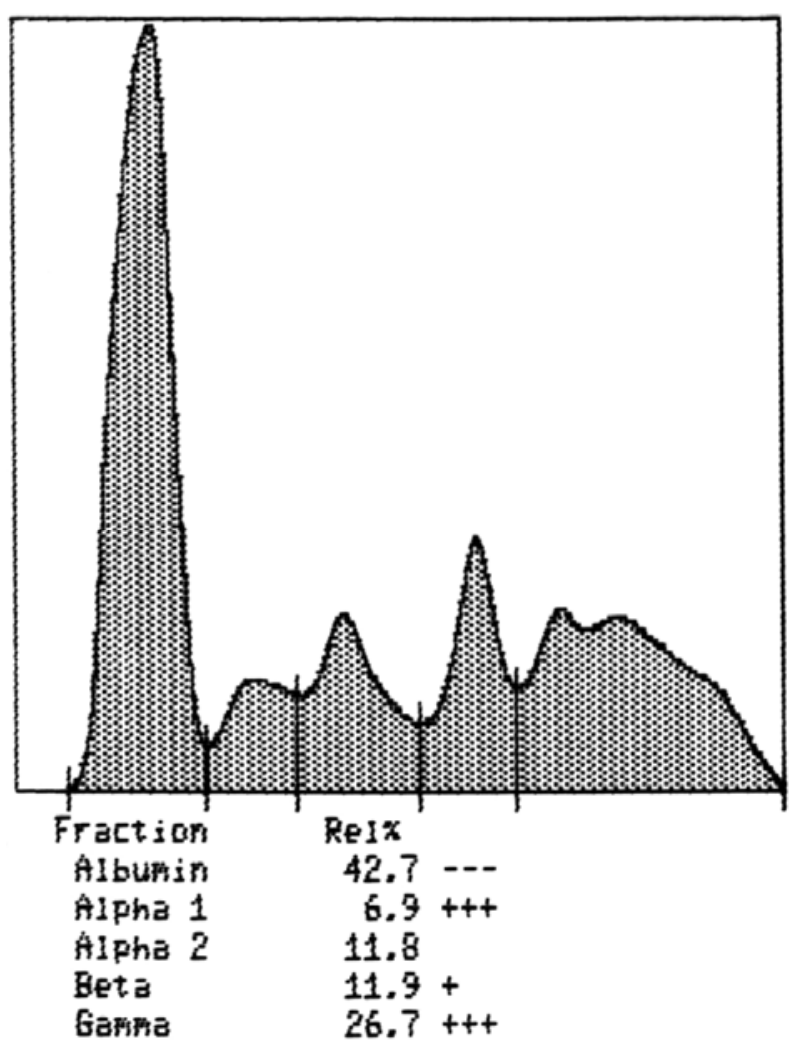

Şekil 6: Sağlıklı danalarda (aşılamadan önce) serum protein bantlarının dansitometrik değerlendirilmesi

Figure 6: Dansitometric evaluation of protein bands in healthy calves (before vaccination)

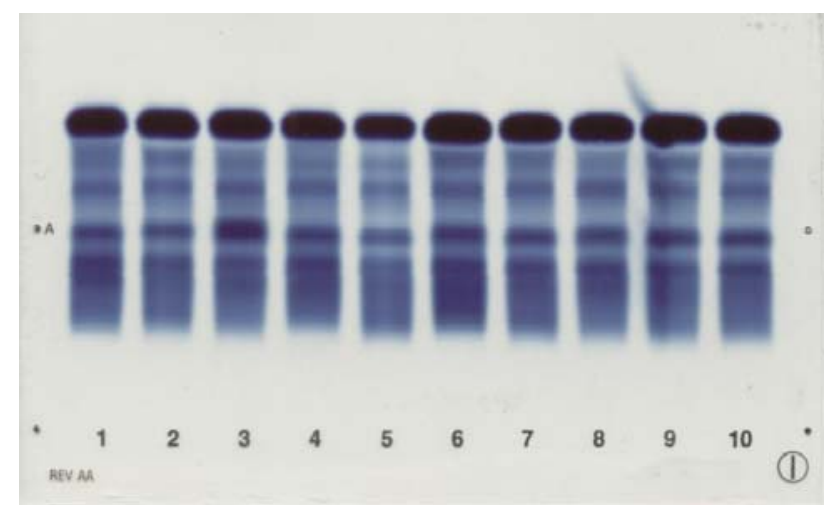

Şekil 7: Aş1lı danalarda serum proteinlerine ait elektroforez bantlar1

Figure 7: Serum protein electrophoresis bands in vaccinated calves

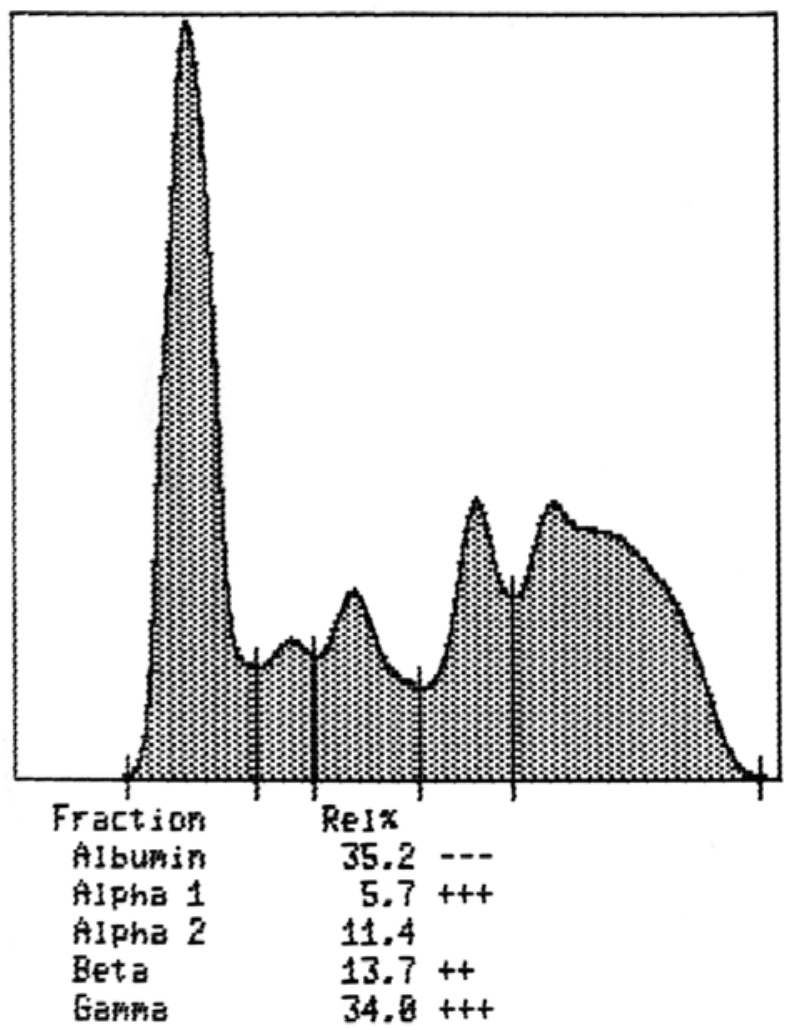

Şekil 8: Aşılı danalarda serum protein bantlarının dansitometrik değerlendirilmesi

Figure 8: Dansitometric evaluation of protein bands in vaccinated calves

Şap hastalığ oluşturulan danalarda, şap hastalığ oluşturulmadan önceki sağlıklı ve hastalığın klinik tesbit edildiği dönemlerde, toplam protein $(\mathrm{g} / \mathrm{dL})$ ve serum protein elektroforezi ile belirlenen yüzde albumin, alfa-1globulin, alfa-2-globulin, beta-globulin, gama-globulin düzeyleri arasında gözlenen farklılıklar istatistik olarak anlamlı bulunmamıştır ( $\mathrm{p} \geq 0.05$ ) (Tablo 1).

Şap hastalığına karşı aşılanan danalarda, aşılama öncesi sağlıklı ve aşılama sonrası dönemlerde toplam 
Tablo 2: Sağlıklı ve şap hastalığına karşı aşılanan danalarda serum proteinlerinin elektroforetik dağılımı Table 2: Electrophoretic distribution of serum proteins of healthy and vaccinated calves against FMD

\begin{tabular}{lcccccc}
\hline Serum proteinleri & $\mathrm{n}$ & Kontrol & Aş11 & $\mathrm{T}$ & Df & Sig. \\
\hline Toplam protein (g/dL) & 10 & $7.14 \pm 0.12$ & $7.72 \pm 0.20$ & -2.528 & 9 & 0.032 \\
Albumin (\%) & 10 & $42.29 \pm 0.76$ & $35.76 \pm 0.41$ & 7.303 & 9 & 0.000 \\
Alfa-1-globulin (\%) & 10 & $6.80 \pm 0.21$ & $6.92 \pm 0.32$ & -0.484 & 9 & 0.640 \\
Alfa-2-globulin (\%) & 10 & $10.64 \pm 0.26$ & $11.29 \pm 0.21$ & -1.910 & 9 & 0.088 \\
Beta-globulin (\%) & 10 & $11.49 \pm 0.38$ & $13.07 \pm 0.71$ & -1.924 & 9 & 0.086 \\
Gama-globulin (\%) & 10 & $28.79 \pm 0.49$ & $32.96 \pm 0.57$ & -6.571 & 9 & 0.000 \\
\hline
\end{tabular}

protein $(\mathrm{g} / \mathrm{dL})$ düzeyleri arasında belirgin bir fark saptanamamıştır ( $\mathrm{p} \geq 0.05$ ) (Çizelge 3.2.). Serum protein elektroforezi ile belirlenen yüzde albumin, alfa-1globulin, alfa-2-globulin, beta-globulin, gama-globulin düzeyleri arasında gözlenen farklılıklardan ise sadece albumin ve gama-globulin düzeyleri arasındaki farklar istatistik olarak anlamlı bulunmuştur ( $\mathrm{p} \leq 0.001)$ (Tablo 2).

Tablo 1 ve 2 de görüldüğü üzere hastalık oluşturulmadan veya aşılanmadan önceki sağlıklı dönemde alınan sonuçlarla karşılaştırıldığında, sadece aşılama sonrası dönemde albumin seviyesinde önemli bir azalma ve gama-globulin seviyesinde önemli bir yükselme olduğu görülmektedir $(\mathrm{p} \leq 0.001)$. Diğer serum protein parametrelere ilişkin değişiklikler istatistik olarak önemli değildir.

\section{Tartışma ve Sonuç}

Şap hastalığının hayvanlar üzerinde yaptığ metabolik değişiklikleri inceleme amacıyla hücre kültürlerinde çok sayıda araştırma yapılmıştır. Canlı hayvan üzerinde gerçekleştirilen metabolik çalışmalar ise bu hayvanların bulunma güçlüğü, pahalı oluşları, yapılan araştırmanın pratik olmaması ve kolay takip edilememesi nedeniyle azdir $(7,11,13,17,19)$.

Plazma proteinlerinin sentezlendiği yer özellikle karaciğerdir. Plazmada \% 5-7 (50-70 g/L veya 5-7 g/dL) protein bulunur. Plazma proteinleri başlica albumin, globulin ve fibrinojenden ibarettir. Albumin ve globulin fraksiyonlarının alt fraksiyonları da mevcuttur (9).

Plazma protein düzeyleri toplam proteinlerin albumin ve globulin fraksiyonlarının elektroforetik olarak ayrılmasıyla değerlendirilir. Karaciğer, hemen hemen tüm plazma proteinlerini sentezlediğinden bunların derişimlerinin ölçümü, karaciğer fonksiyonlarının değerlendirilmesinde klinik biyokimya açısından da oldukça önemlidir (8).

Şap hastalıklı ve şap hastalığına karşı aşılanmış danalarda serum proteinlerinden albumin, alfa-1globulin, alfa-2-globulin, beta-globulin ve gama-globulin düzeyleri agaroz jel elektroforez ile belirlenerek hastalığın protein metabolizması ile ilgili yönüne katkı sağlanmasının amaçlandığı bu çalışmada, danalardan sağlanan toplam protein düzeylerinin normal değerler arasında kaldığı kabul edilebilir $(1,8)$. Sağlıklı ve şap hastalıklı gruplara ait $8.54 \pm 0.25$ ve $8.36 \pm 0.32 \mathrm{~g} / \mathrm{dL}$ değerler normal sınır kabul edilen üst değerin (6.74-7.46 $\mathrm{g} / \mathrm{dL})$ üzerinde gözükse de hastalık ve aşılama öncesi dönemler ile şap hastalıklı ve aşılı dönemlerde danalardan sağlanan serum örneklerinde toplam protein düzeyleri arasındaki sayısal farklılıklar istatistik olarak önemli bulunmamıştır ( $\mathrm{p} \geq 0.05)$.

Bu çalışmada albumin seviyesindeki önemli azalma aşılı danalarda belirlenmiş olup, toplam protein düzeyine göre \% $42.29 \pm 0.76$ olan albumin seviyesi \% 35.76 \pm 0.41 düzeyine gerilemiştir. Bu durum plazma/serum proteinlerinin başlıca sentez yeri olan karaciğerin, immunite sonucu diğer proteinlerin sentezindeki yoğunluğuna bağlanmıştır. Globulinlerden gama-globulin seviyesindeki artış bu düşünceyi doğrulamaktadır. Gamma-globulin düzeyleri yönünden sağlıklı ve aşılı gruplar arasındaki farklılık istatistik olarak anlamlıdır ( $\mathrm{p} \leq 0.001)$. Sağlıklı ve şap hastalıklı gruplar arasındaki \% albumin düzeylerinde gözlenen farklılıklar ise önemli değildir ( $p$ $\geq 0.05$ ). Sağlıklı sığırlarda agaroz-jel elektroforez ile bildirilen albumin düzeyleri 30.3-35.5 g/L'dir (8).

$\mathrm{Bu}$ çalışmada globulinler yönünden önemli bulunan farklılık, gama globulin düzeylerine ilişkin olarak sağlıklı ve aşılanmış danalara ait gruplar arasında gözlenmiștir. Aşılanmış danalarda gama globulin seviyesi \% $28.79 \pm 0.49$ 'dan \% 32.96 \pm 0.57 düzeyine yükselmiştir. $\mathrm{Bu}$ artış istatistik olarak da önemlidir ( $\mathrm{p} \leq 0.001)$. Diğer globulin fraksiyonları açısından gruplar arasında gözlenen farklılıklar önemli bulunmamıştır ( $p \geq 0.05$ ). Globulinlerden sadece gama-globulin düzeyi şap hastalıklı ve aşılı danalarda normal değer olarak bildirilen 16.9$22.5 \mathrm{~g} / \mathrm{L}$ 'nin üzerindedir (8).

Sağlıklı ve şap hastalıklı gruplar arasında serum protein düzeyleri arasında istatistik öneme sahip farklılıkların bulunmaması, hastalığın patogenez ve immunolojisi ile ilgili olarak daha uzun sürede immun yanıtın oluşturulmasına bağlanmıştır. İnaktif viruslarla aşılamada, daha kısa süreli, ancak daha düşük affiniteye ve antikor titresine sahip immun yanıt oluşmaktadır (14). $\mathrm{Bu}$ nedenle de danalarda daha kısa sürede ortaya çıkan immun yanıta bağlı olarak serum protein fraksiyonlarındaki değişiklikler ortaya çıkmakta ve bu özellikle gama- 
globulin düzeylerinde kendisini belirgin olarak göstermektedir.

Sonuç olarak, deneme gruplarından elde edilen sonuçlar ile hastalık oluşturulmadan veya aşılanmadan önceki sağlıklı döneme ait sonuçlar karşılaştırıldığında, sadece aşılama sonrası dönemde albumin seviyesinde önemli bir azalma ve gama-globulin seviyesinde önemli bir yükselme olduğu $(\mathrm{p} \leq .0 .001)$ tesbit edilmiş olup, bu değişikliklerin inaktif viruslarla aşılamada organizma tarafindan daha kısa sürede oluşturulan immun yanita bağlı olduğu ve bu immun yanıtın protein metabolizması ile ilişkisine bağlı olarak da serum protein fraksiyonlarındaki değişikliklerin ortaya çıktığı kanaatine varılmıştır.

\section{Teşekkür}

Bu çalışmada kullanılan materyalin sağlandığı T.C. Tarım ve Köyişleri Bakanlığı Şap Enstitüsü Müdürlüğü’ne teşekkür ederiz.

\section{Kaynaklar}

1. Altıntaş A, Fidancı UR (1993): Evcil hayvanlarda ve insanda kanin biyokimyasaln normal değerleri. Ankara Univ Vet Fak Derg, 40, 173-186.

2. Bölükbaşı F, Yılmaz B, Emre B, Sulu N, Öztürkmen A (1987): Şap virusu ile enfekte edilmiş kobay ve danalarda fizyolojik çalışmalar II. Elektrokardiyografi. Ankara Univ Vet Fak Derg, 34, 349-62.

3. Bush BM (1991): Interpretition of Laboratory Results for Small Animal Clinicians. Blackwell Scientific Publications, London.

4. Coşkuner A (2003): Şap Virusu ile Enfekte ve Aşıll Danalarda Lipid Metabolizması Yönünden Araştırmalar. Doktora Tezi, Ankara Üniversitesi Sağlık Bilimleri Enstitüsü.

5. Düzgüneş O, Kesici T, Gürbüz F (1983): İstatistik Metodları. Ankara Üniversitesi Ziraat Fakültesi Ders Kitabı, 229, Ankara Üniversitesi Basımevi, Ankara.

6. Gürhan Sİ (1989): Şap hastalığının epidomiyolojisi. Vet Hek Der Derg, 59, 1-2.

7. Gürhan Sí (1993): Türkiye'de İzole Edilen A ve O Tipi Şap Virusu Suşlarının Antijenik Varyasyonlarının SDSPAGE Ille Incelenmesi. Doktora Tezi, Selçuk Üniversitesi Sağlık Bilimleri Enstitüsü, Konya.

8. Kaneko JJ, Harvey JW, Bruss ML (1997): Clinical Biochemistry of Domestic Animals. $5^{\text {th }}$ Edition. Academic Press, New York.

9. Karagül H, Altıntaş A, Fidancı UR, Sel T (2000): Klinik Biyokimya. Medisan, Ankara
10. Kitching RP, Rendle R, Ferris NP (1988): Rapid correlation between field isolates and vaccine strains of foot and mouth disease virus. Vaccine, 6, 403-408.

11. Kızıl S, Altıntaş A (2001): Şap hastalıklı siğırlarda süt ve kanda vitamin $A$, vitamin $E$ ve selenium düzeyleri. Türk $\mathrm{J}$ Vet Anim Sci, 25, 961-969.

12. Melvin M, Kealey, D (1987): Electrophoresis. Analytical Chemistry by Open Learning Series. Wiley, London.

13. Nascimento JA (1974): Metabolic studies on hearth of unveaned rabbits infected with F.M.D.V. Arch Vet Res, 35, 1459-1461.

14. Pay TWF, Hingley PH, Radlett PJ, Black L, O'Reilly KJ (1983): The correlation of 140S antigen dose with the serum neutralising antibody response and with protection from challenge induced by FMD (foot-and-mouth disease) vaccines. European Commission for the Control of Footand-Mouth Disease. Research Group of the Standing Technical Committee. Lelystad (Netherlands). FAO, Rome, Report No. FAO-AGA--EUFMD/RG/83, 52-55.

15. Prinsen BCMT, Sain-Van Der Velden MGM (2004): Albumin turnover: experimental approach and its application in health and renal diseases. Clinica Chimia Acta, 347, 1-14.

16. Rueckert RR (1996): Picornaviridae and their replication. In: Virology. $3^{\text {rd }}$ Ed., Lippincott-Raven, New York, 609-645.

17. Sobrino F, Saiz M, Jiménez-Clavero MA, Nunez JI, Rosas MF, Baranowski, E, Ley V (2001): Foot-andmouth disease virus: a long known virus, but a current threat. Vet Res, 32, 1-30.

18. Sütçü M (1985): Şap Hastalı̆̆g. Şap Enstitüsü Yayınları No:2, Ankara

19. Şahal M, İmren HY, Özlem MB, Tanyel B (1994): Süt ineklerinde şap hastalığ ve diabetes mellitus arasındaki ilişki. Ankara Univ Vet Fak Derg, 41, 169-181.

20. Weichselbaum TE (1949): An accurate and rapid method for the determination of protein in small amounts of blood serum and plasma. Am J Clin Path, 10, 40-49.

21. Westermeier R (2001): Electrophoresis in Practice. Wiley-VCH Verlag GmbH, Weinheim, Germany.

Geliş tarihi: 08.01.2008 / Kabul tarihi: 06.03.2008

Yazışma adresi:

Prof. Dr. Ulvi Reha Fidancl

Ankara Üniversitesi

Veteriner Fakültesi

Biyokimya Anabilim Dalı

06110, Dışkapı/Ankara

E-Posta : fidanci@veterinary.ankara.edu.tr 